\title{
TREATMENT OF SOLID WASTE LEACHATE BY ELECTROCOAGULATION TECHNOLOGY
}

\author{
C.B. Shivayogimath ${ }^{1}$, Chandrakant Watawati ${ }^{2}$ \\ ${ }^{1}$ Professor \& Head of the Department, Civil Engineering, Basaveshwar Engineering College, Bagalkot \\ cb_shivayogimath@rediffmail.com \\ ${ }^{2}$ Assistant Professor, Department of Civil Engineering, VSM Institute of Technology, Nipani, cswatawati@gmail.com
}

\begin{abstract}
This paper presents, treatment of solid waste leachate by Electrocoagulation (EC) technique using aluminum electrodes. The sample of leachate was collected from Bagalkot Municipal solid waste (MSW) site. The effects of process variables such as pH, applied cell voltage, and operating time were investigated on COD and turbidity removal. The EC process was carried out in a batch reactor of 1 liter capacity and samples of $750 \mathrm{ml}$ were taken out for batch at 05, 10, 15, 20, 25, 30, 35 and 40 minutes of operation. Results obtained from the experiments showed that COD and turbidity removal was strongly influenced by the initial pH. The highest COD and turbidity removal efficiency of $95.8 \%$ and $96.6 \%$ were obtained at an applied cell voltage of for $9 \mathrm{~V}$, 40 minutes of operation.
\end{abstract}

Keywords: Electro coagulation (EC), Leachate, Chemical Oxygen Demand (COD), Turbidity and Aluminum electrode.

\section{INTRODUCTION}

Land filling is one of the most popular methods of MSW disposal due to its relative simplicity in terms of disposal procedures and low cost [1]. The degradation of the organic fraction of the municipal solid waste in landfill in combination with the percolation of rain water produces a liquid called leachate. One of the main problems with the solid waste landfill sites is leachate depending on large amounts of organic matter, ammonia nitrogen, heavy metals, and chlorinated organic and inorganic salts [2]. Leachate has a complex structure and high pollutant load, and its treatment is quite hard to meet the discharge standards. Therefore, many pretreatment and combined treatment methods are biological treatment methods, membrane processes, advanced oxidation techniques, coagulation-flocculation methods, lagoon and wetland applications have been examined in the literature [3]. Chemical composition of landfill leachate depends on several factors including waste composition, site hydrogeology, specific climatic conditions, moisture routing through the landfill, landfill age as well as design and operation of the landfill [1]. The rapid increase in the waste generation has increased the land usage also. In solid waste management, the most common technique for final disposal of solid waste over the world is sanitary landfill. However, leachate becomes an issue as a wastewater sources since it may cause serious pollutions to ecosystem [4]. The heavy metals that commonly found in high concentrations in leachate are iron, manganese, zinc, chromium, lead, copper and cadmium. Therefore, more technological development had been done in various countries to treat the landfill leachate [4].
Electro coagulation (EC) is an electrochemical wastewater treatment technology that has been used in treating effluents containing suspended solids, oil and grease, and even organic and inorganic pollutants that can be flocculated. In India EC technology has been successfully adopted for the treatment of the textile dye wastewater [5], purification of wastewater [6], tannery wastewater [7] and domestic wastewater [8]. This method is characterized by simple equipment and easy operation. The EC processes have lesser amount of sludge and the EC process have been successfully used in removal of COD as high as $81 \%$ from landfill leachate [9], 74.08\% from landfill leachate [4] and the removal efficiency of turbidity were high as $95 \%$ [10].

The objective of the present paper is to investigate the influencing parameters which can contribute to high removal of COD and turbidity in landfill leachate by EC processes using aluminum electrodes.

\section{MECHANISM OF EC}

Water is also electrolyzed in a parallel reaction, producing small bubbles of oxygen at anode and hydrogen at the cathode. Electro coagulation, precipitation of ions (heavy metals) and colloids (organic and inorganic) using electricity has been known as an ideal technology to upgrade water quality for a long time and successfully applied to a wide range of pollutants. Electro coagulation is the technique to create conglomerates of the suspended, dissolved or emulsified particles in aqueous medium using electrical current causing production of metal ions at the expense of sacrificing electrodes and hydroxyl ions as a result of water 
splitting. Metal hydroxides are produced as a result of EC and act as coagulant/flocculent for the suspended solids to convert them into flocs of enough density to be sediment under gravity. Destabilization of the contaminants, particulate suspension, breaking of emulsions, and aggregation of the destabilized phases to form flocs. The reactions occurring in an EC process using aluminum anode and cathode can be referred in Eqn. 1, 2 and 3 as represented below.

The oxidation reaction at the anode,

$$
\mathrm{Al} \rightarrow \mathrm{Al}^{+3}+3 \mathrm{e}^{-}
$$

The reduction reaction at the cathode,

$$
3 \mathrm{H}_{2} \mathrm{O}+3 \mathrm{e}^{-} \rightarrow 1.5 \mathrm{H}_{2}+3 \mathrm{Al}^{-}
$$

Net Equation;

$$
\mathrm{Al}+3 \mathrm{H}_{2} \mathrm{O} \rightarrow \mathrm{Al}(\mathrm{OH})_{3}+1.5 \mathrm{H}_{2} \mathrm{O}
$$

\section{MATERIALS AND METHODS}

The experimental setup of monopolar parallel EC unit is shown in Fig. 1. The EC container was made of plastic and has dimensions $80 \mathrm{~mm}$ diameter and $100 \mathrm{~mm}$ height. The aluminum electrodes with dimensions of $90 \mathrm{~mm} \times 30 \mathrm{~mm} \times$ $1 \mathrm{~mm}$ were used as cathode and anode. After the initial characterization of leachate, batch experiments were conducted to optimize the various parameters. The studies were performed with four electrodes connected to the DC power supply to determine optimum condition. The space between electrodes was maintained $1.5 \mathrm{~cm}$ in all the experiments. In each run the voltage was varied to a desired value of 3,6, and 9V. The volume of solution in each batch experiment was $0.75 \mathrm{~L}$. To maintain homogenous mixing of the reactor content, magnetic stirring unit was used. Electrodes should be washed before every experiment. EC experiments were performed for $40 \mathrm{~min}$ and in each run samples are retrieved at every 5 minutes interval for analysis.

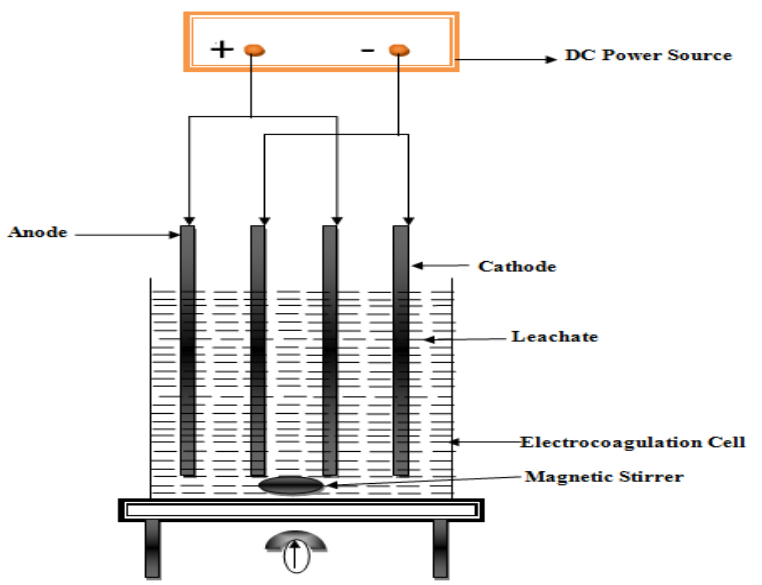

Fig.1 Experimental setup
The study was carried out using leachate collected from Bagalkot MSW site which is situated $4 \mathrm{~km}$ away from the city centre. The characteristics of the leachate are shown in Table1.

Table.1 Characteristics of solid waste leachate

\begin{tabular}{|l|c|}
\hline \multicolumn{1}{|c|}{ Particulars } & Concentration \\
\hline $\mathrm{pH}$ & 5.8 \\
Color & yellow \\
Total suspended solids $(\mathrm{mg} / \mathrm{L})$ & 718 \\
COD $(\mathrm{mg} / \mathrm{L})$ & 4820 \\
Conductivity $(\mu \mathrm{S} / \mathrm{cm})$ & 2441 \\
Total solids $(\mathrm{mg} / \mathrm{L})$ & 900 \\
Turbidity $(\mathrm{NTU})$ & 89 \\
Total Dissolved Solids $(\mathrm{mg} / \mathrm{L})$ & 182 \\
\hline
\end{tabular}

\section{RESULTS AND DISCUSSION}

\subsection{Effect of Cell Voltage and pH on COD Removal}

The experimental setup is shown in Fig. 1. It describes the effect of cell voltage on COD removal efficiency. When leachate was treated without $\mathrm{pH}$ adjustment i.e. at $\mathrm{pH} 5.8$ (Fig.2), the COD removal efficiency increased with electrolysis time (ET) up to 35 minutes afterwards no change was observed. However the figure showed that, maximum COD removal of $95.8 \%$ was obtained at ET of 35 minutes at cell voltage $9 \mathrm{~V}$, during this period COD reduced from 4820 to $198 \mathrm{mg} / \mathrm{L}$. When $\mathrm{pH}$ was reduced to 4.0 (Fig.3), COD removal increases with ET however maximum COD removal efficiency of $73.6 \%$ was obtained be at ET of 35 minutes of at $9 \mathrm{~V}, \mathrm{COD}$ reduced from 4820 to $1270 \mathrm{mg} / \mathrm{L}$. When $\mathrm{pH}$ was increased moving towards alkaline condition at $\mathrm{pH} 8.0$ (Fig.4), maximum COD removal efficiency $82.3 \%$ was obtained at ET of 35 minutes at cell voltage of $9 \mathrm{~V}$, during this period COD reduced from $4820 \mathrm{mg} / \mathrm{L}$ to $850 \mathrm{mg} / \mathrm{L}$. Comparing all the three figures, maximum COD removal efficiency of $95.8 \%$ was obtained at $\mathrm{pH} 5.8$ with voltage of $9 \mathrm{~V}$ during an ET of 35 minutes. 


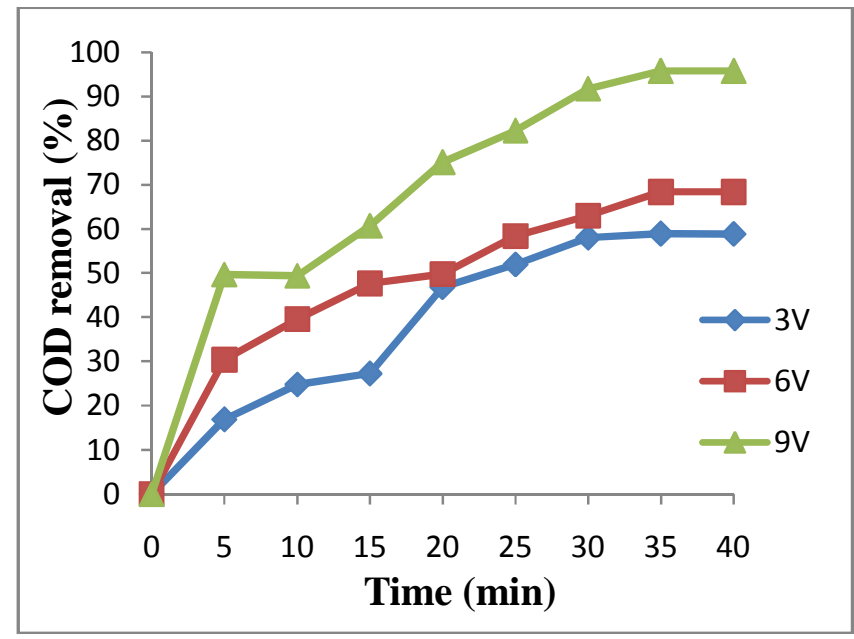

Fig. 2 COD removal with ET at different voltages ( $\mathrm{pH}$ : 5.8)

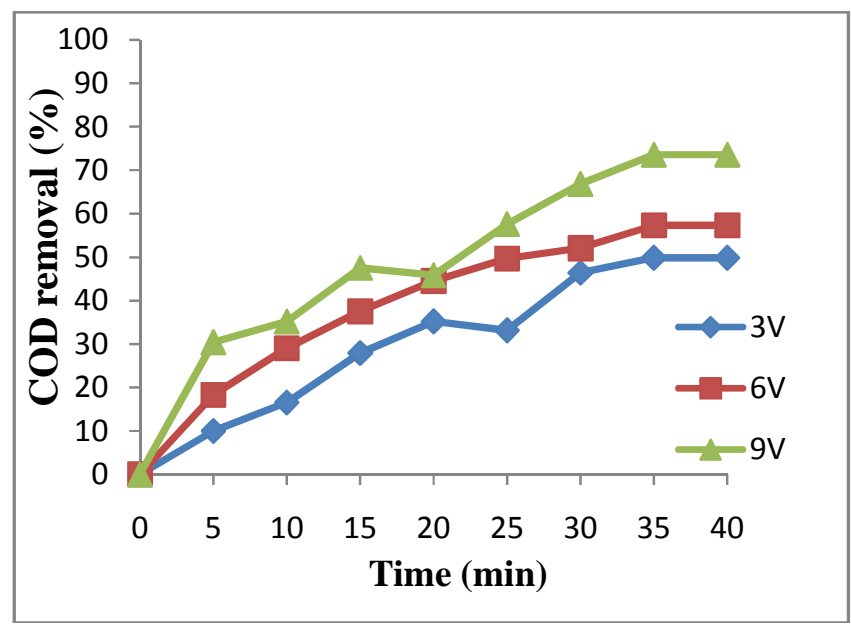

Fig. 3 COD removal with ET at different voltages ( $\mathrm{pH}: 4.0)$

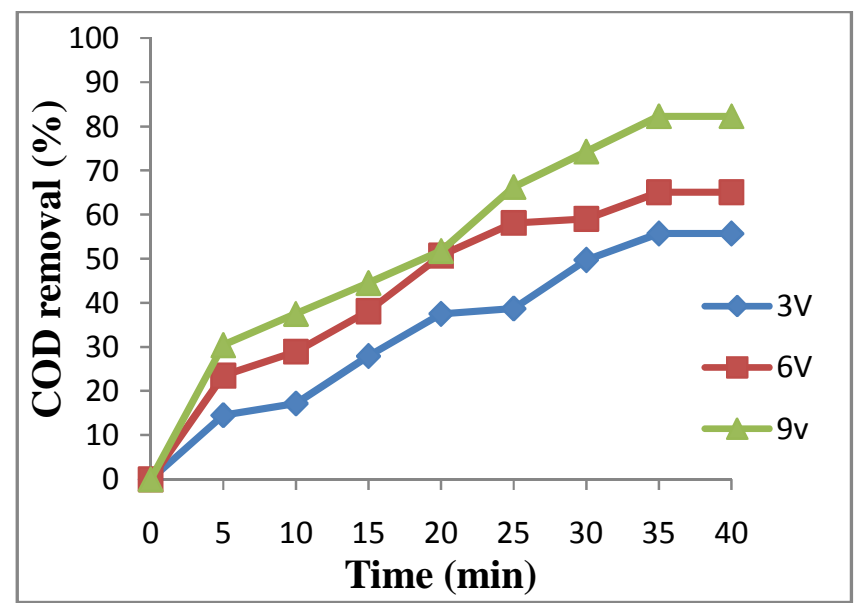

Fig. 4 COD removal with ET at different voltages (pH: 8.0)

\subsection{Effect of Cell Voltage and $\mathrm{pH}$ on Turbidity}

\section{Removal}

The effects of $\mathrm{pH}$ and cell voltage at varying ET are presented in the following section. In all the cases (Fig. 5, 6 and 7) the turbidity removal increased with ET and cell voltage up to 35 minutes. However maximum turbidity removal of $96.6 \%$ was obtained at $\mathrm{pH} 5.8$ and cell voltage $9 \mathrm{~V}$. At this condition the turbidity reduced from 89 NTU to 3 NTU.

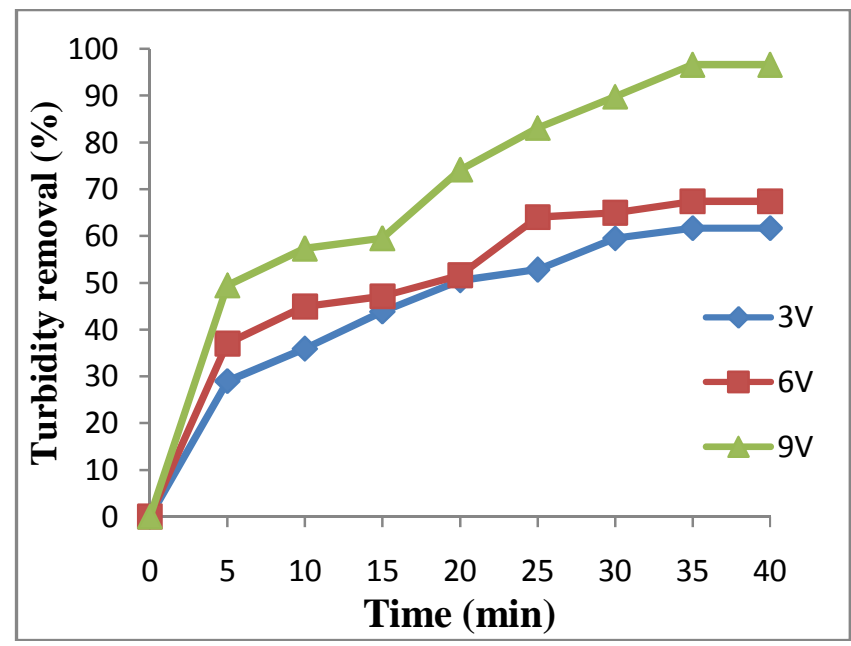

Fig. 5 Turbidity removal with ET at different voltages $(\mathrm{pH}$ : 5.8)

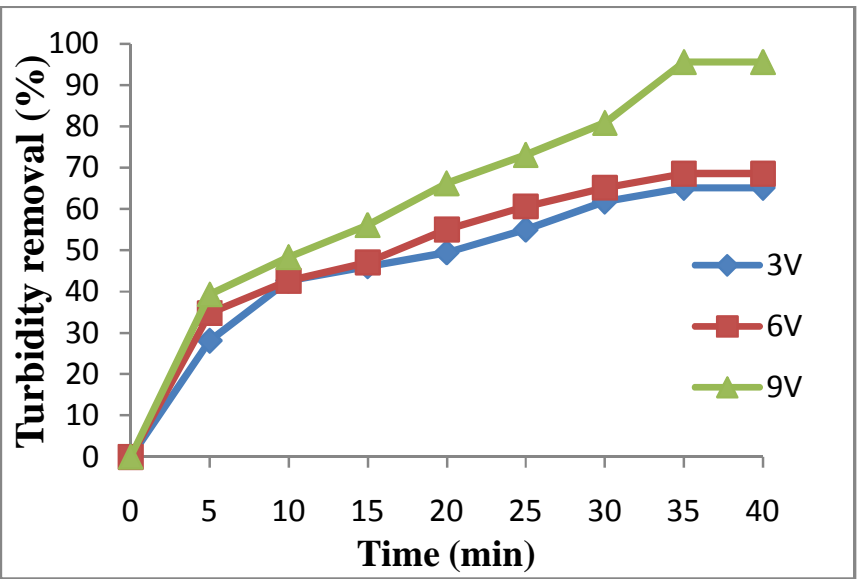

Fig. 6 Turbidity removal with ET at different voltages $(\mathrm{pH}$ : 4.0) 


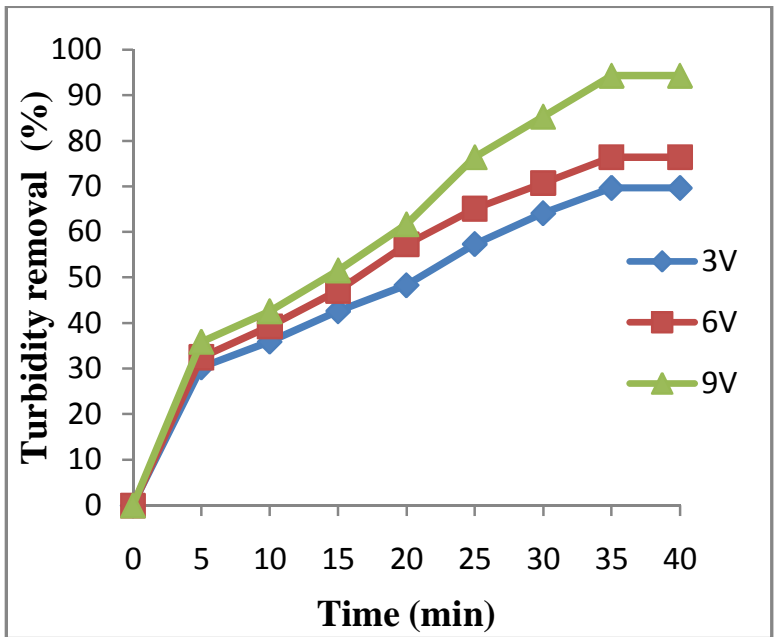

Fig. 7 Turbidity removal with ET at different voltages $(\mathrm{pH}$ : 8.0)

\section{CONCLUSIONS}

The study investigated the removal of COD from a landfill leachate characterized by high COD concentration. It was found that, operating parameters such as electrolysis time, $\mathrm{pH}$ and voltage significantly affected the treatment of landfill leachate. The optimum COD and turbidity removal of $95.8 \%$ and $96.6 \%$ respectively were obtained at a very short ET of 35 minutes cell voltage of $9 \mathrm{~V}$ with leachate $\mathrm{pH}$ as 5.8 . Further, use of aluminum as sacrificial electrode material in the treatment of landfill leachate was found to be very sensitive for changes in $\mathrm{pH}$. Finally the results of study showed that, EC technology could be applied for the cost effective treatment of landfill leachate.

\section{REFERENCES}

[1] Noor Ainee Zainol, Hamidi Abdul Aziz, Mohd Suffian Yusoff and Muhammad Umar, "The use of Poly aluminum Chloride for the treatment of Landfill Leachate Via Coagulation and Flocculation processes", Research Journal of Chemical Sciences, Vol. 1(3), pages 34-39 (2011).

[2] Tuba Yilmaz, Selami Apaydin and Ali Berktay, "Coagulation-Flocculation and Air Stripping as a Pretreatment of Young Landfill Leachate", The Open Environmental Engineering Journal, Vol. 3, pages 4248 (2010).

[3] Faith Ilhan, Ugur Kurt, Omer Apaydin, and M. Talha Gonullu, "Treatment of leachate by Electrocoagulation using aluminum and iron electrodes", Journal of Hazardous Materials 154, pages 381-389 (2008).

[4] Rosie Jotin, Shaharin Ibrahim and Normala Halimoon, "Electrocoagulation for removal of chemical oxygen demand in sanitary landfill leachate", International
Journal of Environmental Sciences, Vol. 3, No. 2, pages $921-930$ (2012).

[5] Usha N Murthy, H.B Rekha and J.G Bhavya, "Electrochemical treatment of textile dye wastewater using stainless steel electrode", International Conference on Environmental and Computer science, pages 64-68 (2011).

[6] A. K. Chopra, Arun Kumar Sharma and Vinod kumar, "Overview of Electrolytic treatment: An alternative technology for purification of wastewater", Scholars research library, pages 191-206 (2011).

[7] R. Ramesh Babu, N.S. Bhadrinarayana, K.M.Meera Sheriffa Begum and N.Anantharaman, "Treatment of tannery wastewater by Electrocoagulation", Journal of university of chemical technology and metallurgy, pages 201-206 (2007).

[8] C. Sarala, "Domestic wastewater treatment by electrocoagulation with $\mathrm{Fe}-\mathrm{Fe}$ electrodes", International Journal of engineering trends and technology, Vol. 3, pages 530-533 (2012).

[9] Masoumeh MoayeriKashani, Salman Masoudi Soltani and S. Sobri, "Treatment of Malaysian Leachate Sample Using Electrocoagulation", International Journal of Chemical Engineering and Applications, Vol. 3, No. 1, pages 63-66 (2012).

[10] Moh Faiqun Ni'am, Fadil Othman, Johan Sohaili and Zulfa Fauzia, "Removal of COD and Turbidity to improve wastewater quality using Electrocoagulation Technique" The Malaysian Journal of Analytical Sciences, Vol. 11, No.1, pages 198-205 (2007). 